\title{
Particulate Matter 2.5 with Impaired Lung Function on Children: A Systematic Review
}

\author{
Mega Utami Basra ${ }^{1}$ \\ \{megautamibasra@ph.unand.ac.id ${ }^{1}$ \} \\ ${ }^{1}$ Department of Epidemiology and Biostatistics, Faculty of Public Health, Andalas University, Padang, \\ Indonesia
}

\begin{abstract}
Particulate Matter $2.5\left(\mathrm{PM}_{2.5}\right)$ is generated from the combustion process, including exhaust fumes from motor vehicles, industrial activity, and forest fires. This review aims to find out $\mathrm{PM}_{2.5}$ as one of the risk factors of impaired lung function on children through a critical review of the article journals. A systematic review strategy was conducted by searching for articles related to $\mathrm{PM}_{2.5}$ with impaired lung function on children that already published in accredited journals from 2012-2017. The literature search was conducted in April 2017 through the online database, Pubmed, ProQuest, and Science Direct database. Seven article journals selected based on the inclusion criteria and the exclusion criteria that conducted with the critical review process. This systematic review showed the significant result that $\mathrm{PM}_{2.5}$ is one of the risk factors for impaired lung function on children. The higher the average concentration of $\mathrm{PM}_{2,5}$, the more decrease of lung function on children. Children, as one of the susceptible groups of $\mathrm{PM}_{2.5}$, need more protection and preventive actions, especially with forest fires that happened in Indonesia.
\end{abstract}

Keywords: $\mathrm{PM}_{2.5}$, Impaired Lung Function, Children

\section{Introduction}

$\mathrm{PM}_{2.5}$ is a particulate with a diameter of 1-2.5 microns. $\mathrm{PM}_{2.5}$ is generated from the combustion process, including exhausting fumes from motor vehicles. $\mathrm{PM}_{2.5}$ is also produced from chemical reactions between various gases such as sulfur dioxide, nitrogen dioxide, and VOCs (Volatile Organic Compounds). $\mathrm{PM}_{2.5}$ may exacerbate heart disease and lung disease and has been linked to several effects such as cardiovascular disease, heart attack, respiratory disorders, asthma attacks, emphysema, and bronchitis. Community groups susceptible to $\mathrm{PM}_{2.5}$ exposure include having a history of heart disease or lung disease, the elderly, and children [1]. PM 2.5 can be in the atmosphere indefinitely. Currently, $\mathrm{PM}_{2.5}$ is believed to be a major contributor to various human health problems, because the particulate can enter and block the smallest tubes contained in the lungs. Some studies have found that particulates smaller than $2.5 \mu \mathrm{m}$ give worse effects on the respiratory system than larger particles. $\mathrm{PM}_{2.5}$ can reach the bronchioles and alveoli. Then, it will accumulate in the respiratory tract, then it increases the risk of respiratory problems, inhibit the development and function of the lungs, and the most severe is the increased mortality due to respiratory and cardiovascular diseases [2]. 
PM concentrations are higher in urban areas than in rural areas, which may be caused by more motor vehicle emissions in cities than in villages. The PM concentration in the room depends on the source of the combustion from the room [3]. The study by Choo et al. found that kindergarten schools (TK) in urban areas had higher concentrations of $\mathrm{PM}_{2.5}$ than rural areas. The prevalence of cough and high-frequency breathing sounds that were heard at the end of expiration (wheezing) was significantly higher among urban kindergarten children than in the village. This study proves that the increase in air pollution has adverse effects, especially on the development of respiratory function in childhood. Statistically, it was found that there was a significant relationship between exposure to high $\mathrm{PM}_{2.5}$ indoors with an increased risk of respiratory distress in children [4].

Exposure to $\mathrm{PM}_{2.5}$ can already occur since prenatal time. $\mathrm{PM}_{2.5}$ concentrations indoors and exposure to prenatal cigarette smoke, affecting bronchiolitis and lower respiratory tract infections [5]. In preschool-aged children, there was an effect of increased $\mathrm{PM}_{2.5}$ concentration with the progression of bronchitis [6]. A study by Martinez et al. found a link between the Forced Expiratory Volume in the first second (FEV1) and Forced Vital Capacity (FVC) with air pollution [7], especially particulates with a small size of $2.5 \mu \mathrm{m}$ [8].

\section{Materials and Methods}

This review is a systematic review with the implementation of a literature search strategy to ensure all relevant literature is covered in this search. Furthermore, the articles will be assessed to get a conclusion in accordance with the purpose of this study; to know the exposure of $\mathrm{PM}_{2,5}$ with impaired lung function in children. The search for articles is done by searching for articles related to $\mathrm{PM}_{2.5}$ with impaired lung function in children that already published in accredited journals. My literature search was conducted in April 2017 through the online database, Pubmed, ProQuest, and Science Direct database. In addition, I also searched for the Environmental Health Perspectives journal because it relates to the theme of my review. The keywords used were "PM 2.5 and Impaired Lung Function" and the search year is limited from 2012 to 2017. Journals and articles obtained were filtered by title and abstract. The selected articles were based on the desired criteria, while the journals that were not relevant to the research topic were issued. The selected journals were evaluated using inclusion and exclusion criteria, based on the criteria separated from which the journal was eligible for review.

Table 1. Inclusion and Exclusion Criteria

\begin{tabular}{ll}
\hline Inclusion & Exclusion \\
\hline Published from 2012-2017 & Published before 2012 \\
$\mathrm{PM}_{2,5}$ & Didn't explain about $\mathrm{PM}_{2,5}$ \\
Outcome: Impaired Lung Function & Outcome didn't explain about Impaired Lung \\
& Function \\
Focused on children & Focused on Adult or older people \\
\hline
\end{tabular}




\section{Result}

There were 2033 articles in the Pubmed, ProQuest, and Science Direct database plus 77 articles from the Environmental Health Perspectives journal that found after the author searched using the keyword. After that, the articles' title was scanned based on the inclusion criteria. There were 2047 articles issued because of incompatibility with the research criteria. Then, there were 63 articles abstracts left to be reviewed. After that, 38 remaining articles still compatibled with the criteria and then reviewed by the full script. Finally, seven articles appropriated for the final full script review.

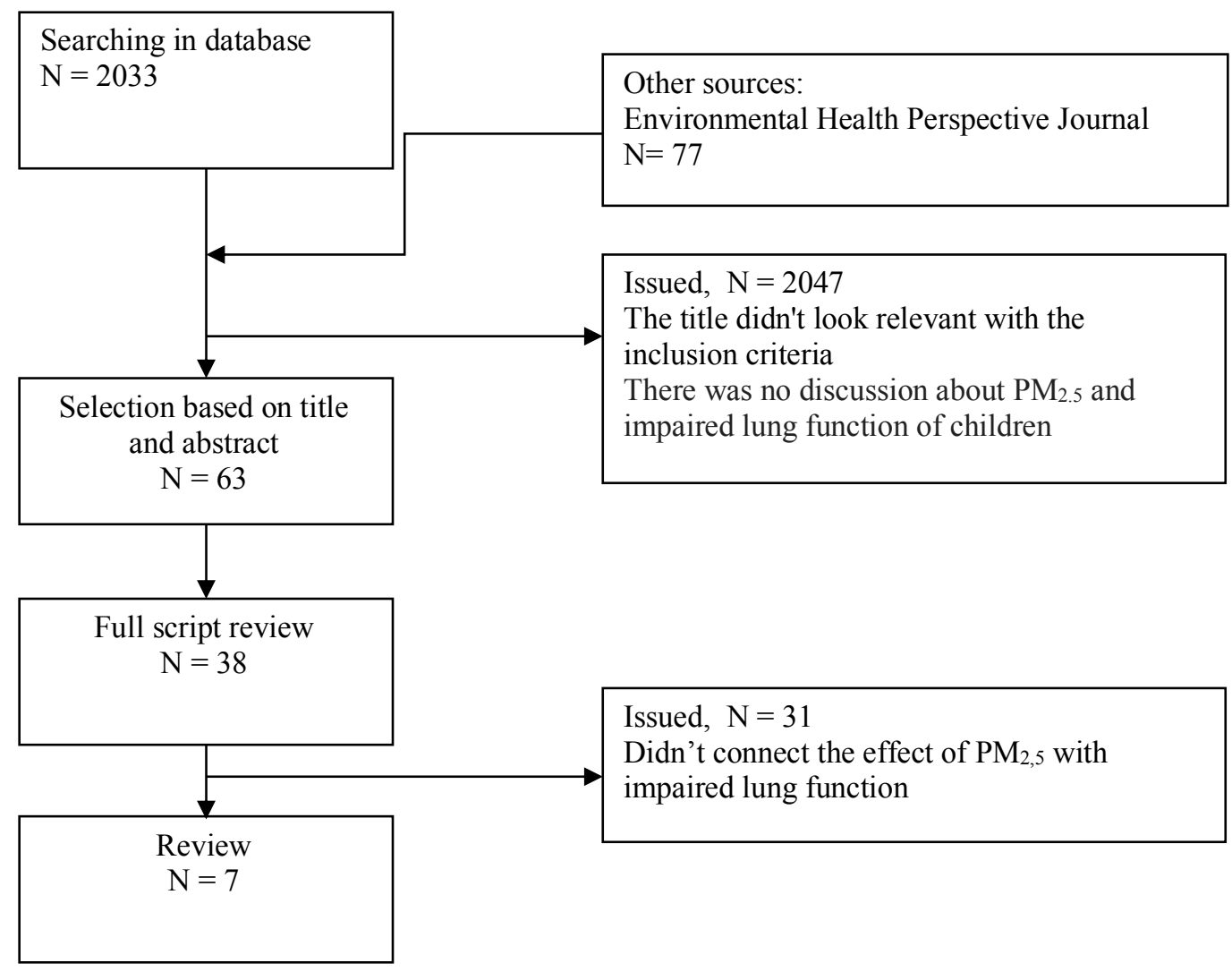

Fig. 1. Systematic review

From 7 articles that had been reviewed, there were four articles used prospective cohort design, two articles used retrospective cohorts, and one article used a cross-sectional design. Table 
2 consists of relevant article findings, including author, research's year, research location, subject or exposure, research questions, research study design, samples, and results/ conclusions.

Table 2. Critical appraisal

\begin{tabular}{|c|c|c|c|c|}
\hline $\begin{array}{l}\text { Authors, } \\
\text { Research's } \\
\text { year, } \\
\text { Location }\end{array}$ & Aim of the study & Study design & Sample & Result \\
\hline $\begin{array}{l}\text { Hwang et } \\
\text { al. } 2007- \\
2009 \text {. } \\
\text { Taiwan }\end{array}$ & $\begin{array}{l}\text { Assess the } \\
\text { relationship between } \\
\text { exposure to air } \\
\text { pollution and the } \\
\text { development of lung } \\
\text { function and to } \\
\text { examine the potential } \\
\text { differences in sex } \\
\text { susceptibility to air } \\
\text { pollution }\end{array}$ & $\begin{array}{l}\text { Prospective } \\
\text { Cohort }\end{array}$ & $\begin{array}{l}2941 \text { children } \\
\text { who didn't } \\
\text { smoke }\end{array}$ & $\begin{array}{l}\text { Decreases in FVC, FEV1, and } \\
\text { FEF were associated with } \\
\text { increased } \mathrm{PM}_{2.5} \text { exposure. } \\
\text { Decreased lung function was } \\
\text { greater in boys than girls. }\end{array}$ \\
\hline $\begin{array}{l}\text { Chen at al., } \\
2011 . \\
\text { Taiwan }\end{array}$ & $\begin{array}{l}\text { To recognize the } \\
\text { chronic and } \\
\text { subchronic effects of } \\
\text { ambient air pollution } \\
\text { on lung function and } \\
\text { compare it among } \\
\text { children of different } \\
\text { ages }\end{array}$ & $\begin{array}{l}\text { Cross- } \\
\text { sectional }\end{array}$ & $\begin{array}{l}1494 \\
\text { schoolchildren } \\
6-15 \text { years old } \\
\text { at } 44 \text { schools } \\
\text { on } 24 \text { sub- } \\
\text { districts in } \\
\text { Taiwan }\end{array}$ & $\begin{array}{l}\text { The increase in } \mathrm{PM}_{2.5} \text { was } \\
\text { associated with a decrease in } \\
\text { FEV1 / FVC and MMEF / FVC. } \\
\text { On children age 6-15 years old } \\
\text { that got chronic exposure to } \mathrm{PM}_{2.5} \\
\text { will lead to decreased lung } \\
\text { function and it founded that there } \\
\text { were some damages to the texture } \\
\text { of the children respiratory tracts } \\
\text { that associated with } \mathrm{PM}_{2.5} \text {. }\end{array}$ \\
\hline $\begin{array}{l}\text { Gehring et } \\
\text { al. } 2012 \text {. } \\
\text { Germany, } \\
\text { Sweden, } \\
\text { Netherland, } \\
\text { UK }\end{array}$ & $\begin{array}{l}\text { To determine the } \\
\text { relationship between } \\
\text { exposure to air } \\
\text { pollution in the } \\
\text { population with lung } \\
\text { function in five } \\
\text { cohort studies in } \\
\text { Europe. }\end{array}$ & $\begin{array}{l}\text { Retrospective } \\
\text { Cohort }\end{array}$ & $\begin{array}{l}5921 \text { Children } \\
\text { aged 6-8 years } \\
\text { old. }\end{array}$ & $\begin{array}{l}\text { Air pollution exposure reduces } \\
\text { lung function in school-aged } \\
\text { children. FEV1 changed between } \\
-1.77 \%(95 \% \mathrm{CI}:-3.34,-0.18 \%) \\
\text { for increased of } 5-\mu \mathrm{g} / \mathrm{m} 3 \mathrm{PM}_{2.5}\end{array}$ \\
\hline $\begin{array}{l}\text { Meng } \\
\text { Wang et al., } \\
2014 . \\
\text { Netherlands }\end{array}$ & $\begin{array}{l}\text { Evaluate the } \\
\text { relationship between } \\
\text { long-term air } \\
\text { pollution exposure } \\
\text { using two modeling } \\
\text { techniques of } \\
\text { exposure and to } \\
\text { compare estimates of }\end{array}$ & $\begin{array}{l}\text { Retrospective } \\
\text { Cohort }\end{array}$ & 1,058 children & $\begin{array}{l}\text { Predictions of LUR and dispersion } \\
\text { models were positively associated } \\
\text { with } \mathrm{PM}_{2.5} \text { and } \mathrm{NO}_{2}\end{array}$ \\
\hline
\end{tabular}




\begin{tabular}{|c|c|c|c|c|}
\hline & $\begin{array}{l}\text { the relationship } \\
\text { between long-term air } \\
\text { pollution exposure } \\
\text { and lung function in } \\
\text { children using the } \\
\text { modeling technique }\end{array}$ & & & \\
\hline $\begin{array}{l}\text { Watanabe } \\
\text { et al., } 2015 . \\
\text { Japan }\end{array}$ & $\begin{array}{l}\text { To know the effects } \\
\text { of PM on the lungs of } \\
\text { school-aged children } \\
\text { and their potential for } \\
\text { an inflammatory } \\
\text { response }\end{array}$ & $\begin{array}{l}\text { Prospective } \\
\text { cohort }\end{array}$ & $\begin{array}{l}339 \text { children } \\
\text { aged } 10-12 \\
\text { years old }\end{array}$ & $\begin{array}{l}\text { The increase in } \mathrm{PM}_{2.5} \text { was } \\
\text { associated with a decrease in PEF } \\
(-1.72 \mathrm{~L} / \mathrm{min}) \text {. There were } \\
\text { significant relationships between } \\
\mathrm{PEF}, \mathrm{SPM} \text {, and } \mathrm{PM}_{2.5} \text {. }\end{array}$ \\
\hline $\begin{array}{l}\text { Fuertes et } \\
\text { al., } 2015 . \\
\text { Germany }\end{array}$ & $\begin{array}{l}\text { To determine the } \\
\text { relationship between } \\
\text { exposure to air } \\
\text { pollution at residence } \\
\text { and lung function in } \\
15 \text { years of life in two } \\
\text { German birth cohort } \\
\text { studies }\end{array}$ & $\begin{array}{l}\text { Prospective } \\
\text { cohort }\end{array}$ & $\begin{array}{l}2266 \text { children } \\
\text { aged } 15 \text { years } \\
\text { old that live in } \\
\text { city and } \\
\text { village }\end{array}$ & $\begin{array}{l}\text { Exposure to long-term air } \\
\text { pollution is not associated with } \\
\text { lung function }\end{array}$ \\
\hline $\begin{array}{l}\text { Cuicui } \\
\text { Wang et al. } \\
\text { 2014-2015. } \\
\text { Shanghai }\end{array}$ & $\begin{array}{l}\text { To evaluate the short- } \\
\text { term effects of } \mathrm{PM}_{2.5} \\
\text { exposure on lung } \\
\text { function and see the } \\
\text { potential role of } \\
\text { CC16 on this effect }\end{array}$ & $\begin{array}{l}\text { Prospective } \\
\text { cohort }\end{array}$ & $\begin{array}{l}36 \text { healthy } \\
\text { students }\end{array}$ & $\begin{array}{l}\mathrm{PM}_{2.5} \text { exposure is negatively } \\
\text { related to lung function }\end{array}$ \\
\hline
\end{tabular}

\section{Discussion}

More than half of the studies show that there was a significant relationship between $\mathrm{PM}_{2.5}$ exposure and impaired lung function in children. The results of research by Hwang et al. from 2007 to 2009 in Taiwan on 2941 non-smoked children found that there was a decrease in Forced Vital Capacity (FVC), Forced Expiration Volume in 1 second (FEV1), and Forced Expiratory Flow (FEF) if there was an increase in exposure to $\mathrm{PM}_{2.5}$. For example, the higher $\mathrm{PM}_{2.5}$ exposure (IQR, $17.92 \mu \mathrm{g} / \mathrm{m}^{3}$ ) was associated with $75 \mathrm{~mL}$ FVC decline in boys and $61 \mathrm{~mL}$ in girls $(\mathrm{p}<0.05)$. The decline is more common in boys than girls [9]. The results of the study by Chen et al. 2011 in Taiwan on 1494 schoolchildren 6-15 years old at 44 schools in 24 sub-districts in Taiwan found that lung function changed every average increase of $\mathrm{PM}_{2.5}$ for two months $(12 \mu \mathrm{g} / \mathrm{m} 3,32-44)$ was -103 on FVC, -86 on FEV1 and $-102 \mathrm{ml} / \mathrm{s}$ at MMEF. $\mathrm{PM}_{2.5}$ was associated with a decrease in the ratio of FEV1 / FVC and MMEF / FVC. On children aged 6-10 years, damage to respiratory tract structures in the lung may be associated with $\mathrm{PM}_{2.5}$ exposure [10]. Then, the results of research by Gehring et al. in 2012, in Germany, Sweden, the Netherlands, and the UK, on 5921 
children aged 6-8 years old also found a decrease in maximal expiratory expression in 1 second (FEV1) of $-1.77 \%$ (95\% CI: $-3.34,-0.18 \%$ ) for 5- $\mu \mathrm{g} / \mathrm{m} 3$ escalation of $\mathrm{PM}_{2.5}$ [11]. Meng Wang et al. in 2014 in the Netherlands studied 1,058 children using two exposure modeling techniques named LUR and dispersion-modeled. Concentrations were found to be high for $\mathrm{NO}_{2}$ and $\mathrm{PM}_{2.5}(\mathrm{R}$ $=0.86-0.90)$ [12]. Watanabe et al. in 2015 conducted a study of 339 children aged 10-12 in Japan. $\mathrm{He}$ found that an increase of $10 \mathrm{mg} / \mathrm{m}^{3} \mathrm{PM}_{2.5}$ was associated with a decrease in PEF $(-1.72 \mathrm{~L} /$ $\min )[13]$.

Many other epidemiological studies have proven significant associations between $\mathrm{PM}_{2.5}$ and pulmonary function. However, not all studies have found it because it depends on climatic conditions and mixtures of other pollutants. Fuertes et al. in 2015 conducted a study of 226615 year-olds living in urban and rural Germany. Fuertes found that long-term air pollution was not related to lung function [14]. Cuicui Wang et al. research from 2014 to 2015 in Shanghai on 36 healthy and non-smoking students found that $\mathrm{PM}_{2.5}$ exposure was negatively associated with lung function. However, Wang found that the acute effect on $\mathrm{PM}_{2.5}$ could be an immediate decrease in lung function because it impairs the integrity of the pulmonary epithelium [15]. Children are more susceptible to the effects of air pollution. The development of the lungs of children is still not perfect at birth. Lung development occurs by the proliferation of the alveoli and capillaries up to two years of age. Then, alveolus expansion will develop until the age of 5-8 years. The lungs will continue to develop during adolescence and will be perfect as adults $[16,17]$. Infants and children have higher levels of metabolic fatigue and higher levels of oxygen consumption than adults. This is because children are still in a period of rapid growth and development and have a very active physical activity. It causes exposure to air pollution to be riskier to health. Another cause is the need for higher children's oxygen, and children have narrower airways than adults, so air pollution that provides a small response in adults will have a more severe effect on the breathing of children [18].

\section{Conclusion}

Half of the studies have found that $\mathrm{PM}_{2.5}$ results in impaired lung function in children. The higher the average concentration of $\mathrm{PM}_{2,5}$, the more decrease in lung function. However, some studies didn't find the $\mathrm{PM}_{2.5}$ relationship with lung function. It is due to climatic factors at the site and the presence of a mixture of other contaminants. It needs further research that shows the difference in the outcome of lung function disorder with $\mathrm{PM}_{2.5}$ on children, especially because of forest fires that happened in Indonesia.

\section{References}

[1] EPA, "Airborne Particulates," ed. Queensland: Environment Protection Agency, 2006.

[2] WHO, "Outdoor Air Pollution," C. s. H. a. t. Environment, Ed., ed: World Health Organization, 2008. 
[3] R. A. O. Nunes, P. T. B. S. Branco, M. C. M. Alvim-Ferraz, F. G. Martins, and S. I. V. Sousa, "Particulate matter in rural and urban nursery schools in Portugal," Environmental Pollution, vol. 202, pp. 7-16, 2015.

[4] C. P. Choo, J. Jalaludin, T. R. Hamedon, and N. M. Adam, "Preschools Indoor Air Quality and Respiratory Health Symptoms Among Preschoolers in Selangor," Procedia Environmental Sciences, vol. 30, 2015.

[5] S. I. Yang, E. Lee, Y. H. Jung, K. Y. Choi, and M. J. Kang, "Effect Of Prenatal Exposure To Indoor PM2.5 and Environmental Tobacco Smoke Affecting Lower Respiratory Tract Infection Was Modified By ROS Genes: Cocoa Study," Journal Allergy Clin Immunol, vol. vol. 133, 2012.

[6] R. J. Sram, B. Binkova, M. Dostal, M. Merkerova-Dostalova, H. Libalova, A. Milcova, et al., "Health Impact of Air Pollution to Children," International Journal of Hygiene and Environmental Health, vol. 216, 2013.

[7] R. Martinez, P. Padilla, O. Fernandez, M. Alvarado, M. Macias, and Fortoul, "Lung function growth in children with long-term exposure to air pollutants in Mexico City " American Journal of Respiratory and Critical Care Medicine vol. 176, pp. 377-384, 2007.

[8] J. Gauderman, Avol, Gilliland, Vora, Thomas, Berhane, et al., "The Effect of Air Pollution on Lung Development from 10 to 18 Years of Age," New England Journal of Medicine, vol. 351, pp. 1057-1067, 2004.

[9] B.-F. Hwang, Y.-H. Chen, Y.-T. Lin, X.-T. Wu, and Y. L. Lee, "Relationship between Exposure to Fine Particulates and Ozone and Reduced Lung Function in Children," Environmental Research, vol. 137, pp. 382-390, 2015.

[10] C.-H. Chen, C.-C. Chan, B.-Y. Chen, T.-J. Cheng, and Y. L. Guo, "Effects of Particulate Air Pollution and Ozone on Lung Function in Non-Asthmatic Children," Environmental Research, vol. 137, pp. 40-48, 2015.

[11] U. Gehring, O. Gruzieva, R. M. Agius, R. Beelen, A. Custovic, J. Cyrys, et al., "Air Pollution Exposure and Lung Function in Children: The ESCAPE Project," Environmental Health Perspectives, vol. 121, pp. 1357-1364, 2013.

[12] M. Wang, U. Gehring, G. Hoek, M. Keuken, S. Jonkers, R. Beelen, et al., "Air Pollution and Lung Function in Dutch Children: A Comparison of Exposure Estimates and Associations Based on Land Use Regression and Dispersion Exposure Modeling Approaches," Environmental Health Perspectives, vol. 123, pp. 847-851, 2015.

[13] M. Watanabe, H. Noma, J. Kurai, H. Sano, D. Hantan, M. Ueki, et al., "A Panel Study of Airborne Particulate Matter Composition Versus Concentration: Potential for Inflammatory Response and Impaired Pulmonary Function in Children," Allergology International, vol. 66, pp. 52-58, 2017.

[14] E. Fuertes, J. Bracher, C. Flexeder, I. Markevych, C. K. B. Hoffmann, U. Krämer, et al., "Long-term Air Pollution Exposure and Lung Function in 15 Year-Old Adolescents Living in An Urban and Rural Area in Germany:The GINIplus and LISAplus Cohorts," International Journal of Hygiene and Environmental Health, vol. 218, pp. 656-665, 2015.

[15] C. Wang, J. Cai, R. Chen, J. Shi, C. Yang, H. Li, et al., "Personal Exposure to Fine Particulate Matter, Lung Function and Serum Club Cell Secretory Protein," Environmental Pollution, pp. $1-6,2017$. 
[16] S. Selevan, "Identifying critical windows of exposure for children's health.," Environmental Health Perspectives, vol. 108, p. 451, 2000.

[17] WHO, "Children's Health and the Environment - A global perspective. A resource guide for the health sector,," ed: World Health Organization, 2005.

[18] J. Moya, "Children's behavior and physiology and how it affects exposure to environmental contaminants," Pediatrics, vol. 113, p. 996, 2004. 